Turkish Online Journal of Qualitative Inquiry (TOJQI)

Volume 12, Issue 2, April 2021: 133-172

DOI: $10.17569 /$ tojqi. 754028

Research Article

\title{
Muslim and Christian Peer Images in Turkish-German Muslim Children's Human Figure Drawings ${ }^{1}$
}

Yasemin Güleç ${ }^{2}$

\begin{abstract}
In this study, the religious social perceptions and friendship relations of Turkish-German Muslim children between the ages of 7-14 about their religious groups and their host Christian peers were examined. 42 students, including 17 girls and 25 boys, participated in the study. Here children's drawings were benefited as a primary source of information and a diagnostic method in which secondary information (open-ended questions) were directed. The data were analyzed by descriptive qualitative analysis method based on the research questions. In this study, it was seen that religious indicators, signs, and symbols (religious-social images) emerged effectively through the drawing method. Theological semiotic may be used as a diagnostics method in more studies in determining the development of religious concepts in children. The number of religious differences in the drawings increased with age. It was understood that 9-14-year-old children could make religious categorization in interviews about drawings and responses concerning open-ended questions. In-group favoritism and in-group friendship preferences increased with age. At the same time, as age increased, moral reasoning in choosing friendship increased.
\end{abstract}

Keywords: Theological semiotic, religious social images, religious social categorization, religious prejudice, interreligious friendships

1 This research titled "Muslim and Christian Peer Images in Turkish-German Muslim Children's Human Figure Drawings" was approved by Hacı Bektaş Veli University Ethics Committee with the number 08 meeting dated 12.03.2020.

2 Assist.Prof.Dr. Nevşehir Hacı Bektaş Veli University, Faculty of Theology, Department of Philosophy and Religious Sciences, yasemingulec@nevsehir.edu.tr, https://orcid.org/0000-0001-8843-3270.

Received: 17.06.2020, Accepted: 11.02.2021 


\title{
Türk-Alman Müslüman Çocukların İnsan Figürü Çizimlerinde Müslüman ve Hristiyan Akran Görüntüleri
}

\begin{abstract}
$\ddot{O} z$
Bu çalışmada 7-14 yaşları arasındaki Türk-Alman Müslüman çocukların kendi dini grupları ve ev sahibi Hristiyan akranları hakkındaki dini sosyal algıları ve arkadaşlık ilişkileri incelenmiştir. Çalışmaya 17 kız 25 erkek olmak üzere 42 öğrenci katıldı. Çalışmada çocuk çizimleri birincil bilgi kaynağı ve ikincil bilgilerin (açık uçlu sorular) yönlendirildiği bir tanı yöntemi olarak kullanılmıştır. Veriler araştırma sorularına dayalı nitel analiz yöntemi ile analiz edilmiştir. Bu çalışmada, dini göstergelerin, işaretlerin ve sembollerin (dini-sosyal imgeler) çizim yöntemi ile etkili bir şekilde ortaya çıktığı görülmüştür. Teolojik göstergebilim çocuklarda dini kavramların gelişimini belirlemek için daha fazla çalışmada tanı yöntemi olarak kullanılabilir. Çizimlerdeki dini farklılıkların sayısı yaşla birlikte artmıştır. 9-14 yaş arası çocukların resimlerle ilgili görüşmelerde ve açık uçlu sorulara verdikleri cevaplarda dini sınıflandırma yapabildikleri anlaşılmıştır. Grup içi taraftarlık ve grup içi arkadaşlık tercihleri yaşla birlikte artmıştır. Aynı zamanda, yaş arttıkça, arkadaşlık seçimindeki ahlaki akıl yürütme de artmıştır.
\end{abstract}

Anahtar Kelimeler: Teolojik göstergebilim, dini sosyal imgeler, dini toplumsal sinıflandırma, dini önyargl, dinler arası arkadaşlıklar 


\section{Introduction}

Studies have found that Muslims in the West are very religious (Voas \& Fleischmann, 2012) and attach great importance to their religious identity (Verkuyten, 2007a; Verkuyten \& Thijs, 2010). This pattern is valid not only for adults but also for the adolescent children of immigrants (de Hoon \& van Tubergen, 2014; Güngör, Bornstein, \& Phalet, 2012; Jacob \& Kalter, 2013), as Muslim parents are very effective in transferring their religion to their children (Soehl, 2017). Consequently, religious Christians or non-religious people mostly live together with religious minority Muslim groups in primarily European countries (Jacob \& Kalter, 2013).

Research on religious identity and behavior of immigrant children in Europe has mostly examined Muslim children. Researches show that the Muslim religious identity constitutes an important social group with a sense of group memberships (Ysseldyk, Matheson, \& Anisman, 2010), especially among second-generation Turkish immigrants in Europe and that ethnic and religious ties coincide (Güngör et al., 2012; Maliepaard, Lubbers, \& Gijsberts, 2010; Verkuyten $\&$ Yildiz, 2007) The religiosity and socialization of parents affect the religiosity of children (de Hoon \& van Tubergen, 2014; Fleischmann \& Phalet, 2011; Jacob \& Kalter, 2013), and the religious identity of migrants could be influenced by the ethnic peers in the neighborhood and at the school (de Hoon \& van Tubergen, 2014; Van Tubergen, 2007; Verkuyten, Thijs, \& Stevens, 2012).

Turkish immigrant workers in Germany come from socio-economically underdeveloped and religious rural areas of Turkish society (Phalet, Güngör, \& Brewster Smith, 2009). Turkish immigrant children in Europe are socially disadvantaged and could encounter ethnic and religious prejudice and discrimination (Heath, Rothon, \& Kilpi, 2008; Savelkoul, Scheepers, Van der Veld, \& Hagendoorn, 2012). Therefore, in this study, it may be considered that Turkish children have a lower social status than German children. Muslims, who make up five percent of the German population, is the most significant religious minority in Germany (Leszczensky \& Pink, 2016). Given some anti-Muslim attitudes in Germany (Savelkoul et al., 2012), it is vital to understand the role of religious borders on children and adolescents' social relations.

In this study, our theoretical basis draws upon social development theories within the study of intergroup relations. Generally, studies on ethnic prejudice formed the basis of our hypothesis 
because ethnic identity includes "abstract features such as values, and customs" (Quintana, 1998). We benefit from Social Reasoning Developmental Theory (SRD), inspiring by (Rutland, Killen, \& Abrams, 2010). The SRD perspective stems from integration "between both developmental psychology and Social Domain Theory" (Turiel, 1983) and "social psychology and SIT" (Tajfel \& Turner, 2004). This perspective recommends a more contextualized analysis of intergroup relations and the development of bias than the earlier-offered development theories. Social domain and social identity approaches, which are the basis of this perspective, consider the contradiction between both the early start of prejudice and moral development in childhood. It shows that children can use moral reasoning and group identity at the same time while developing their ability to think about social relations. At the same time, this social reasoning is the basis of peer evaluation in and between groups (Rutland et al., 2010).

\section{Using Children's Drawings in Determining Social Images and Friendship Relations}

Based on Vygotsky's thought, children's pictures are used as a diagnostic method in this study. According to Vygotsky, in a completed drawing, there is a simultaneity parallel to the definition of thought. While the image appears as a whole, expressions have a linear and temporal nature (Vygotsky, 1962). Perhaps for children (and for adults), the power of drawing is to represent thought more closely. The continuity of a drawing provides opportunities for an extended dialogue relationship that speech cannot. When children are not sufficient in speaking and writing, drawings provide convenience in communicating, giving meaning, and solving a problem (Brooks, 2003a, 2003b).Besides, questionnaires or oral surveys may be tedious, especially for children. However, most children accept drawing (Driessnack, 2005; Pinto \& Bombi, 2008). Drawings are ecological and easy to collect, without linguistic barriers, ideal for cross-cultural comparisons (Golomb, 1992; Krampen, 1991; Pinto \& Bombi, 2008).

In the literature, studies are investigating inter-group racial and ethnic social perceptions (BarTal, 1996; Michael \& Rajuan, 2009; Teichman, 2001; Teichman \& Zafrir, 2003; Yedidia \& LipschitzElchawi, 2012) and friendship relationships (Bombi \& Pinto, 1994; Laghi et al., 2013, 2014; Pinto \& Bombi, 2008; Rabaglietti, Vacirca, Zucchetti, \& Ciairano, 2012) in children by drawing pictures. However, very few studies investigate religious differences and inter-religious relations among the children through drawing (Güleç, 2019). 
“The request to 'draw a person' allows children to freely choose the age, sex, stance, action, and expression of the figure, which is understood to reflect their deep acquaintance with themselves."(Furth, 1989). In the context of this literature, HFD (Human Figure Drawings) was first proposed as a tool for evaluating social images (Dennis, 1966). Then It was stated that HFD might be systematically rated and applied to assess social representations and friendships relation (Bombi, Cannoni, \& Pinto, 2007; Bombi \& Pinto, 1994).This method, which is called "Pictorial Assessment of Interpersonal Relationships (PAIR)," was confirmed to be useful in explaining children's friendship descriptions in later studies (Laghi et al., 2013; Rabaglietti et al., 2012). In another study, HFD was further developed by designing a scoring procedure representing different situations of social perceptions' structure and content and providing versatile information about human perception (Teichman, 2001).

In other studies using the HFD method, different aspects of drawings such as picture complexity, drawing quality, size, and the number of colors used were considered (Teichman, 2001). Yet, in this study, the drawings were not examined from artistic aspects such as depth, fiction, and color. The drawings were used as a primary source of information and a diagnostic method in which secondary information (open-ended questions) were directed.

As far as we know, based on the literature review, there is no qualitative study that investigated religious differences, religious, social perception, and friendship relations between religious groups by using the HFD method. This study has some important aspects in terms of the literature. The first is to be among religious groups. Religious in-group and inter-group research is not sufficient in terms of inter-religious relations and friendship relationships. Additionally, almost all studies have been conducted with quantitative methods resulting in most in-group research being based on these studies' perceptions. The second is to analyze the qualitative analysis method's obtained data without using quantitative criteria previously used in studies with the HFD method. Moreover, researching religious group relationships in children is crucial for alleviating religious tensions (Herriot, 2007), developing inter-religious tolerance, and preparing effective intervention programs (Van der Straten Waillet \& Roskam, 2013).

\section{Children's Understanding of Religion Differences}

According to Social Identity Theory, the individual is connected to a group that contributes to his understanding of the social world by enabling him to define his status in society (Tajfel, 
1981). Thus, since the opinions and values are different in each religious group, each group can exhibit a distinct development feature (Takriti, Barrett, \& Buchanan-Barrow, 2006). In this sense, in the inter-group contexts in multicultural societies, it is important to identify the development of children's religious social identities from different religious groups and when and how they understand religious differences.

Religious social categorization is that the child is aware of the different religions and understand that this difference is related to various religious beliefs (Van der Straten Waillet \& Roskam, 2012a), which may be influenced by socio-cultural factors such as religious group membership, ethnic origin, homogeneity and heterogeneity of school and class, minority or majority group status, parental religious socialization, as well as development factors (Takriti et al., 2006; Van der Straten Waillet \& Roskam, 2012a).

A study was conducted on Catholic/majority and Muslim/minority children between 6 and 11 years of age in Belgium. Students attended religiously homogeneous- at least eighty percent Catholic or at least eighty percent Muslim- and heterogeneous -more than 40 percent did not share the same religion- schools. In the study, 6-7-year-olds did not yet make a complete religious categorization. However, all children at the age of 11 gained this ability (Takriti et al., 2006; Van der Straten Waillet \& Roskam, 2012a). In a qualitative study of "58 Arab Muslims, Asian Muslims, Christian and Hindu children aged 5-11 living in North London," the findings showed that children's religious identity is exposed to a complex structure of influence that cannot be explained only with age or cognitive differences (Takriti et al., 2006). In the study, qualitative data was evaluated, separating these children into three groups based on age. The younger group did not state the religious groups. Young children mostly mentioned that they did not like out-group members. The Middle group expressed more names of religious groups when asked. However, there were confusions about religion, nation, and languages. They were inclined to say places of worship and religious practices such as "praying or fasting." The old group was more likely to provide more information than younger children. Children mostly named the main religions quickly. In some children, negative emotional reactions to the outgroup members continued. But there were more tolerance examples. In another qualitative study investigating Christianity and Christian peer perceptions of Turkish-German Muslim children aged 9-15, the pictures' religious details increased with increasing age. In children's drawings, religious visual icons that contained a literal meaning were seen mostly at the ages of 9-10, 
while more detailed indicators containing religious indexes and symbols were drawn by children aged 11-15 (Güleç, 2019).

It was determined that group status and class composition affect religious social categorization in children. It was found that the minority religious group gained religious categorization earlier than the majority group. Although all children in heterogeneous schools understand religious categorization, only 11-year-olds in homogeneous schools reached this stage. The reason for this may be because of their encountering more religious groups in daily life and use their operational skills. Both minority and majority group children aged 6-8 years in heterogeneous schools knew some religious labels. However, they thought that religious categorization was based on skin color features that were not a defining feature of religious connection. The reason for this could be that children under nine years of age do not fully understand the criterion of belief because of cognitive limitations (Van der Straten Waillet \& Roskam, 2012a).

\section{Development of Prejudice in the Children}

According to the cognitive-developmental perspective, prejudice in children decreases with age (Aboud, 1988; Aboud \& Amato, 2001; Bigler \& Liben, 2006). However, researchers recently have attracted attention to the cognitive development approach's limitations in explaining prejudice (Nesdale, 2008; Rutland, 2004). Unlike the cognitive-developmental perspective, some research has revealed that stereotypes and prejudices also continue in adolescence and adulthood after childhood (Greenwald, McGhee, \& Schwartz, 1998; Rutland, Cameron, Milne, \& McGeorge, 2005).

According to the study of van der Straten Waillet and Roskam (2012b), religious discrimination is common in children under 10-year-olds and decreases in pre-adolescence and adolescence, In contrast, no difference was found between pre-adolescence and adolescence in religious prejudice (Van der Straten Waillet \& Roskam, 2012b). Similarly, in Takriti and colleagues' (2006) study, first and second grades and third and fourth graders children stated they did not like out-group members. However, although some of the negative emotions persisted in some children in the older age group, examples of religious tolerance frequently emerged. Güleç (2019) found that $51 \%$ of students aged $9-11$ had religious prejudice, and $24 \%$ of $12-15$-yearolds had this. 
These different results show that not only cognitive-developmental explanations are sufficient in explaining racial, ethnic, and religious prejudices, but also contextual factors may be influential (McGlothlin \& Killen, 2005, 2006; Takriti et al., 2006; Van der Straten Waillet \& Roskam, 2012a). In this study, group identity, in-group norms and beliefs, and out-groups threat will be discussed as contextual factors related to our research.

\section{Religious Group Identity and In-group Evaluation}

According to the social identity development theory (SIDT) proposed based on the social identity theory (SIT), individuals want to have a safe and positive social identity (Nesdale, 2008). The comparison between groups creates a competitive dynamic in which groups try to increase their identity compared to other groups. An attempt to obtain a superior position based on valuable dimensions for the group is an essential cause of intergroup behavior (Tajfel \& Turner, 2004). However, this does not infer that people always prejudice against the outgroup. In some cases, in-group preferences could lead to outgroup bias and discrimination (Brewer, 1999; Cameron, Alvarez, Ruble, \& Fuligni, 2001). According to SIDT, some children are more think of themselves as a member of the value groups. In this sense, the stronger religious group identity may lead to a better view of their peers in-group and prefer their group. In some cases, this may indirectly cause negative emotions and prejudices toward out-groups. Many studies investigating the bonds between personality characteristics and religious fundamentalism (Altemeyer, 2003; Altemeyer \& Hunsberger, 1992; Jackson \& Hunsberger, 1999; Saroglou, Delpierre, \& Dernelle, 2004) indicated that religious prejudice might occur more among people adhering firmly to religious groups. Altemeyer (2003) found that highly fundamentalist people particularly emphasize their religious group identity during childhood.

In the study of Verkuyten and Thijs (2010), all early adolescent groups who generally had a strong religious group identity had more positive feelings for their group. Muslims had the most positive in-group feelings. Early adolescent Muslims had more religious in-group identity than their Christian peers. Besides, both Christian and Muslim early adolescents with a strong religious identity had more negative feelings towards non-believers than those with a weak religious identity. 


\section{Religious ingroup norms and beliefs}

According to the social identity development theory (SIDT), outgroup assessments may result from ingroup norms, beliefs, and group identity (Nesdale, 2008). Often, religious belief is a strong driving force of compassion (Schwartz \& Huismans, 1995; Seul, 1999), but religious belief is also related to conviction. Indeed, some studies have shown that devout people are directing their kindness to their own or similar religious groups (Dovidio, Gaertner, \& Saguy, 2007; Saroglou et al., 2004).

Some studies show that children tend to increase social representations or social discourses from an early age. For example, in a multinational study among 6-year-olds, was found that outgroup attitudes were impressed by their nation's prevalent belief regarding other nations (Bennett et al., 2004). In the context of the Israeli-Arab conflict, Jewish children reflect their feelings of desperation, as well as their feelings of anger and stereotypes about Arabs, violently and deadly to all Arab figures (Michael \& Rajuan, 2009; Teichman, 2001; Teichman \& Zafrir, 2003; Yedidia \& Lipschitz-Elchawi, 2012).

\section{Religious Out-groups and Threat}

According to SIDT (Nesdale, 2008), group identification, ingroup norms, and beliefs and out of group threat are influential in instigating children's prejudice. SIDT also identified that under identity threatening conditions, people would try to preserve or restore a positive and different collective identity (Tajfel \& Turner, 2004). The threat of identity could cause negative feelings against external groups (Rothgerber \& Worchel, 1997). The perceived outgroup threat to the group's symbolic resources could lead to action to preserve their group culture and values (Tajfel \& Dawson, 1965) and prejudice against outgroups (Kinder \& Sears, 1981; Rothgerber \& Worchel, 1997; Tajfel, 1981).

In religious identity threat, perceived difficulties against a religion or religious community may be seen as a threat to "an individual's values, worldview, culture, family, moral community and social group" (Ysseldyk et al., 2010; Ysseldyk, Matheson, \& Anisman, 2011). Religion as a way of maintaining traditions for immigrants and their children (Cadge \& Ecklund, 2007; Hirschman, 2006) may become a more important social identity for immigrant children in environments where the majority perceives the immigrant minority as a threat (Ysseldyk et al., 
2010). Research on Muslims in Europe shows that the sense of rejection and perceived discrimination of the ethnic and /or religious group to which one belongs is associated with higher ethnic identification and higher immigrant religiosity with their group (Branscombe, Schmitt, \& Harvey, 1999; Çelik, 2015; Connor, 2010; Leszczensky, Flache, \& Sauter, 2019; Verkuyten \& Thijs, 2010).

One study showed that half of the Dutch middle adolescents were open to negative attitudes against Muslims (Velasco González, Verkuyten, Weesie, \& Poppe, 2008). In another study, about one-third of Muslim early adolescents openly stated that they had negative feelings for Christians, and one in four stated negative emotions for non-believers. At least one-third of the Christian and non-religious participants had negative feelings against Muslims. These findings are probably a reason for the perception that Muslims within the group undermines Dutch culture and identity (Verkuyten \& Thijs, 2010). This means that their religious identity faces a high level of threat for Muslim youth in the Netherlands.

\section{Social Domain Theory and Peer Evaluation}

Social domain theory has evaluated prejudice research in childhood from a moral, socialconventional and, psychological perspective (Smetana, 2013; Turiel, 1983). Research using the social domain model has indicated that different contextual factors contribute to various reasoning patterns. It has been found that older children, especially adolescents, reject direct exclusion based on group membership based on gender, race and ethnic origin (Killen \& Stangor, 2001; Phinney \& Cobb, 1996). Another study found that when moral violations are not related to group membership, children use morality and group membership to objectively evaluate their peers (Abrams, Rutland, Ferrell, \& Pelletier, 2008). In a study with Dutch adolescents in the Muslim minority and non-Muslim majority, Muslim children were not tolerant towards those who were offensive to Islam. Non-Muslims were less tolerant of minority rights. These findings suggest that adolescents' group membership influences their social reasoning about moral subjects and the grade of tolerance against others (Verkuyten \& Slooter, 2008). Also, in the context of group status, compared to majority children (Enesco, Navarro, Paradela, \& Guerrero, 2005; Griffiths \& Nesdale, 2006; Kowalski, 2003; Nesdale, Maass, Griffiths, \& Durkin, 2003), minority children mostly paid more importance to social justice, empathy and fairness in friendships (Hitti, Mulvey, \& Killen, 2017; Killen \& Stangor, 2001). 


\section{Religious Intergroup Friendships}

Studies have shown that intra-group preferences play important roles in formation of friendship ties (Hallinan \& Teixeira, 1987; Vermeij, van Duijn, \& Baerveldt, 2009). Immigrant children from the preschool period (Leman et al., 2013) to childhood (Verkuyten \& Kinket, 2000) and from adolescence to youth (Brüß, 2005; Phinney, Ferguson, \& Tate, 1997) tended to show stronger preferences for co-ethnic peers than for inter-ethnic friends.

It is expected that people who share the same religion (religious hemophily) will prefer each other in social relationship and friendship choices, as because this at least points to a broad agreement on their worldviews (Smith, Maas, \& van Tubergen, 2014), and it is easier and more satisfying (Cheadle \& Schwadel, 2012; Windzio \& Wingens, 2014).

Given the strong relationships between ethnic and religious bonds in Turkish immigrants in Europe (Güngör et al., 2012; Maliepaard et al., 2010), the choice of a friend of the same religion leads to friends with the same ethnicity. Recently, religious boundaries between religious groups (especially Christian and Muslim children) have been investigated in school-based friendship networks. Little is known, however, about how religion boundaries affect children and youth friendship preferences in Western Europe. The number of in-group (Windzio \& Wingens, 2014) and inter-group (Leszczensky \& Pink, 2016; Verkuyten \& Thijs, 2010) studies in this field is limited.

In this study conducted using fourth-grade students' (10-year-olds) in-class network data, religious diversity was an important factor in increasing immigrant-native discrimination levels in social networks. In their study, Windzio and Wingens (2014) revealed that Christian children made fewer friends with Muslim children compared to children from other religious groups. Religious diversity can become more important in early adolescence in friendship choices. Because children start to recognize ethnic and religious groups in this period (Ruble et al., 2004), and religious identities become more stable (Lopez, Huynh, \& Fuligni, 2011). If religion can maintain friendship formation in early adolescence, this may lead to long-term religious homogeneous networks of friendship in adulthood (Grossetti, 2005). 
In comparison to peers from other religious groups, children and early adolescents aged 10-11 are generally reluctant to be friends with Muslim peers (Verkuyten \& Thijs, 2010; Windzio \& Wingens, 2014). In another study focusing on the friendship networks of adolescents aged 1314, it was found that Muslim youths preferred to be friends with Muslims, while Christian youths showed no evidence of preference in religious homophily. Higher religiosity for Muslims increased this choice even further. Because Christian and non-religious youth were unwilling to make friends with their Muslim peers (Leszczensky \& Pink, 2016), regardless of their individual religiosity regarding inter-group friendships, Muslim children were separated from non-Muslim children.

\section{Method}

\section{Participants and Procedure}

The purposeful sampling was used for selecting the students to take part in the study. This method focuses on individuals or groups who have experience with a phenomenon (Creswell \& Clark, 2011). Participants consist of Turkish-German Sunni Muslim children whose parents are Turkish and emigrated from Turkey to Germany, born in Germany and educating in German public schools.

42 students, from the German school in Pforzheim and its surroundings, including 17 girls and 25 boys, aged between 7 and 14 participated in the study. There are 13 (31\%) students in the 78 age group, $14(33 \%)$ in the 9-10 age group, $10(24 \%)$ in the $11-12$ age group, and $5(12 \%)$ in the 13-14 age group. According to age groups, the distribution of gender was as follows; there were girls 5 in the 7-8 age group, 8 in the 9-10 age group, 4 in the 11-12 age group, 1 in the 1314 age group. There were boys 8 in the 7-8 age group, six students in the 9-10 age group, six students in the 11-12 age group, four students in the 13-14 age group.

Before starting the research, firstly, the children were asked some questions to see if they recognized the religion and other religious labels to which they belonged. Inspired by the work of Van der Straten Waillet and Roskam (2012a), picture cards depicting people worshiping in different ways at various places of worship were handed out in the children. There were Muslim, Christian, Jewish, Hindu people on these cards. Then the children were asked to write down the features that made people on these cards different and that the names of the religions they knew. Except for 17 children (these children were 5-6 years old), All the children wrote the names of 
at least 2 and at most 3 religions. Children who can not write the name of any religion were taken to the free activity room and asked to draw and paint any picture they wanted. At least the children who can distinguish cards related to Islam and Christianity and can say the worship places, and write the names of these religions on the sheet were included in the study. Then, it was investigated whether children understand religious categorization. First, the children were shown cards about Islam and Christianity again. Inspiring by the work of Sani and Bennett, the following questions (Sani \& Bennett, 2004) were asked about both religions: "What are people of this religion like?" "What do the people of this religion do?" "How do people of this religion believe?" It was accepted that children who could answer the third question (children who express different beliefs regarding the religious groups) know religious categorization. It was understood that other children knew religious labels without knowing religious categorization. Although the children in the 7-8 age group answered sufficiently to one and the second question, it was thought that they could not make religious categorization because of not answering the third question adequately. Since children 9 years and older were able to provide sufficient and meaningful answers to all three questions, they were considered to have made religious categorization. In order to ensure objectivity, the detailed answers of these questions were evaluated by a Muslim Turkish researcher (this researcher) and a Christian German teacher (a different teacher in each school where the study was conducted) for exploratory purposes.

Moreover, all second-generation Turkish Muslim immigrant children could not identify a Muslim individual as a member of their group (All Muslim children living in Germany are not Turkish Muslims. There are also Muslims from other races and ethnic backgrounds.) In order to clarify the issue, the children were asked the following question: Do a Muslim person to be part of your own religion regardless of race and ethnicity? Children who accepted each Muslim person as one of their religious groups were included in the study ( 2 students stated that religion does not constitute a sense of belonging a group for themselves.)

The study based on the views of students studying at Schömberg Schule, Nordstadt Schule, Otterstein Schule, and Brötzinger Schule, where the principal researcher was teaching. In order to better reflect Children' own lives and emotions (Hart, 1992), minimize perspectives of researchers (Morrow \& Richards, 1996), and the groups they belong to, the study was conducted together by a Muslim Turkish (owner) and a German Christian researcher. 
Firstly, students sat in rows (one by one) to prevent them from being influenced by each other. A4 paper, 12 colored crayons boxes, pencils and erasers were distributed to each participant. Then the children were asked to draw "a Muslim and a Christian peer." Drawing time was not limited to enable children to draw freely. This time varied between 15-30 minutes. Afterward, each child was interviewed individually about their drawings. This time ranged from 1-3 minutes. Then open-ended questions were asked about the person they drew. These questions were as follows: i. What is the name of the person you drew? ii. What could be his / her profession? iii. Do person you drew have bad traits. What are these traits? iv. Does drew person have good traits? What are these traits? vi. What are the most remarkable (good or bad) traits of the person you drew? vi. Would you befriend the person you drew? Why? vii. Which religion are the majority of your friends from? viii. How many students are there in your classroom? What religion do these students belong to? Open-ended question time ranged from 7 to 9 minutes. In this study, 20-25 minutes were spent on average for each student.

This research titled "Muslim and Christian Peer Images in Turkish-German Muslim Children's Human Figure Drawings" was approved by Hacı Bektaş Veli University Ethics Committee with the number 08 meeting dated 12.03.2020.

\section{Data Analysis}

The following questions have sought the answer in this study. i. What indicators reflect religious differences in students' drawings? Are there religious stereotypes and prejudices in these indicators? What contextual factors do the stereotypes and prejudices stem from in the indicators stem from? Is there any difference in the number and quality of religious indicators used by age and gender? ii. What are the good and bad moral traits attributed to the in-group and the out-group? Is there a difference in attributing these traits by gender and age? What may contextual factors have been influential in attributing these traits? iii. Which criteria did Muslim children base on their friendships? Are there any differences in these choices by age and gender? iv. What contextual factors may have influenced friendship choices?

The data were analyzed by descriptive analysis signs and symbols reflecting religious differences (only religious differences and religious cultural indicators expressed by students as religious differences were coded), good and bad moral traits, and friendship preferences attributed to peers. The themes were then digitized using the maxqda MAXQDA 2018 software 
and analyzed according to age and gender variables. Furthermore, direct descriptive quotations have been used to reveal broader contextual factors related to themes.

The purpose of digitizing themes and categories in qualitative data with percentages and frequencies is not to make generalizations and look for a relationship between a limited number of specific variables, and this is not the purpose of qualitative data. There are several primary objectives in the quantification of qualitative data (Yıldırım \& Şimşek, 2016). The first is that digitization increases the reliability of qualitative research. The second objective is to reduce subjectivity. It is not meant to objectify qualitative data. Objectivity is a goal that cannot be achieved (Patton, 1987). Numerical analysis of qualitative data is a form of data analysis and could provide a more fair interpretation. Thirdly, quantifying qualitative data to a certain extent could allow some degree of comparison between the themes and categories resulting from the analysis of the data. The fourth objective is to allow a small sample study to be tested on a broader sample through a questionnaire.

\section{Findings}

\section{Peer Appearances Reflecting the Religious Differences in the Drawings}

Table 1

Muslim and Christian Peer Appearances Reflecting the Religious Differences in the Drawings

\begin{tabular}{|c|c|c|c|c|c|c|c|}
\hline & Girl & Boy & $\begin{array}{l}7-8- \\
\text { year- } \\
\text { olds }\end{array}$ & $\begin{array}{l}9-10- \\
\text { year- } \\
\text { olds }\end{array}$ & $\begin{array}{l}11-12- \\
\text { year- } \\
\text { olds }\end{array}$ & $\begin{array}{l}13-14- \\
\text { year- } \\
\text { olds }\end{array}$ & Total \\
\hline \multicolumn{8}{|l|}{ Muslim Peers } \\
\hline \multicolumn{8}{|l|}{$\begin{array}{l}\text { Muslim peer appearances } \\
\text { reflecting the religious differences }\end{array}$} \\
\hline Headscarve & 11 & 0 & 2 & 5 & 4 & 0 & 11 \\
\hline Mosque & 2 & 5 & 0 & 5 & 1 & 1 & 7 \\
\hline Prayer rug & 1 & 2 & 0 & 0 & 2 & 1 & 3 \\
\hline Prayer bead & 1 & 1 & 0 & 0 & 1 & 1 & 2 \\
\hline $\begin{array}{l}\text { Cevşen } \\
\text { (small prayer pouch worn on } \\
\text { necks) }\end{array}$ & 1 & 0 & 0 & 0 & 0 & 1 & 1 \\
\hline Skullcaps & 0 & 2 & 0 & 0 & 1 & 1 & 2 \\
\hline Not smoking & 0 & 1 & 0 & 0 & 0 & 1 & 1 \\
\hline Not drinking alchol & 0 & 1 & 0 & 0 & 0 & 1 & 1 \\
\hline \multicolumn{8}{|l|}{ Christian Peers } \\
\hline $\begin{array}{l}\text { Christian peer appearances } \\
\text { reflecting the religious differences }\end{array}$ & & & & & & & \\
\hline
\end{tabular}




\begin{tabular}{|c|c|c|c|c|c|c|c|}
\hline Cross & 6 & 4 & 1 & 3 & 4 & 2 & 10 \\
\hline Church & 4 & 4 & 1 & 6 & 1 & 0 & 8 \\
\hline Crucifixion & 0 & 2 & 0 & 1 & 1 & 0 & 1 \\
\hline Priest outfit & 2 & 0 & 0 & 1 & 0 & 1 & 2 \\
\hline Bible & 1 & 0 & 0 & 0 & 0 & 1 & 1 \\
\hline Smoking & 0 & 1 & 0 & 0 & 1 & 0 & 1 \\
\hline Drinking alcohol & 0 & 3 & 0 & 0 & 2 & 1 & 3 \\
\hline Eating pork & 0 & 2 & 0 & 1 & 1 & 0 & 1 \\
\hline Using drugs & 0 & 1 & 0 & 0 & 0 & 1 & 1 \\
\hline SUM & $\begin{array}{l}29 \\
(\% 161)\end{array}$ & $\begin{array}{l}29 \\
(\% 121)\end{array}$ & $\begin{array}{l}4 \\
(\% 31)\end{array}$ & $\begin{array}{l}22 \\
(\% 157)\end{array}$ & $\begin{array}{l}19 \\
(\% 190)\end{array}$ & $\begin{array}{l}13 \\
(\% 260)\end{array}$ & 58 \\
\hline \multicolumn{8}{|c|}{$\begin{array}{l}\text { Column percentages } \\
\text { based on the number } \\
\text { of documents }\end{array}$} \\
\hline $\mathrm{N}=$ Documents & 18 & 24 & 13 & 14 & 10 & 5 & 42 \\
\hline
\end{tabular}

Table 1 provides indications of religious differences (See also Appendix 1/Figure 1 and 2). The most common indicators of religious appearance included the headscarf and the cross. The second most used indicator is the mosque and the church. Girls used more religious indicators in their drawings than boys. In the 7-8 age group 4, 9-10 age group 22, 11-12 age group 19, 1314 age group 13 times were used indicators of religious difference.

\section{Moral Characteristics for Muslim Peers by Gender and Age}

Table 2

Good Moral Traits Attributed to Muslim Peers by Gender and Age

\begin{tabular}{|c|c|c|c|c|c|c|c|}
\hline & Girl & Boy & $\begin{array}{l}7-8- \\
\text { year-olds }\end{array}$ & $\begin{array}{l}\text { 9-10- } \\
\text { year-olds }\end{array}$ & $\begin{array}{l}\text { 11-12- } \\
\text { year- } \\
\text { olds }\end{array}$ & $\begin{array}{l}13-14- \\
\text { year- } \\
\text { olds }\end{array}$ & Total \\
\hline \multicolumn{8}{|l|}{ Muslim Peers } \\
\hline \multicolumn{8}{|l|}{ Moral characteristics } \\
\hline \multicolumn{8}{|l|}{ Good moral traits } \\
\hline Trustworthy & 4 & 2 & 0 & 2 & 3 & 1 & 6 \\
\hline Non-brawler & 1 & 2 & 1 & 0 & 2 & 0 & 3 \\
\hline Non-swearer & 0 & 1 & 1 & 0 & 0 & 0 & 1 \\
\hline Accuracy and honesty & 5 & 7 & 2 & 5 & 3 & 2 & 12 \\
\hline Hardworking & 2 & 1 & 0 & 2 & 1 & 0 & 3 \\
\hline Helpful & 14 & 12 & 5 & 11 & 7 & 3 & 26 \\
\hline Friendly & 2 & 2 & 2 & 0 & 1 & 1 & 4 \\
\hline Sharing & 2 & 0 & 0 & 1 & 1 & 0 & 2 \\
\hline Joking & 1 & 0 & 0 & 0 & 1 & 0 & 1 \\
\hline Smiling & 0 & 1 & 0 & 0 & 1 & 0 & 1 \\
\hline Soft-hearted & 1 & 1 & 0 & 2 & 0 & 0 & 2 \\
\hline Fighting for justice & 0 & 2 & 0 & 1 & 1 & 0 & 2 \\
\hline SUM & 32 & 31 & 11 & 24 & 21 & 7 & 63 \\
\hline
\end{tabular}


As seen in Table 2, the girls more expressed their Muslim peers' good traits than boys. Also, as age increased, good traits attributed to Muslim peers increased (See "the column percentages based on the number of documents" (Table 2). There is a continual increase in the number of good moral qualities attributed to Muslim peers from 7 to 12 years of age. However, after the age of 12, this steady increase starts to decline. Nevertheless, the 13-14 age group expressed these characteristics more than the 7-8 age group.

Table 3

Bad Moral Traits Attributed to Muslim Peers by Gender and Age

\begin{tabular}{|c|c|c|c|c|c|c|c|}
\hline & Girl & Boy & $\begin{array}{l}7-8- \\
\text { year-olds }\end{array}$ & $\begin{array}{l}\text { 9-10- } \\
\text { year-olds }\end{array}$ & $\begin{array}{c}11-12- \\
\text { year- olds }\end{array}$ & $\begin{array}{l}\text { 13-14- } \\
\text { year- olds }\end{array}$ & Total \\
\hline \multicolumn{8}{|l|}{ Muslim Peers } \\
\hline \multicolumn{8}{|l|}{ Moral characteristics } \\
\hline \multicolumn{8}{|l|}{ Bad moral traits } \\
\hline Untrustworthy & 2 & 2 & 2 & 0 & 1 & 1 & 4 \\
\hline Brawler & 1 & 4 & 3 & 1 & 1 & 0 & 5 \\
\hline Swearer & 1 & 1 & 1 & 0 & 1 & 0 & 2 \\
\hline Lying & 0 & 2 & 1 & 1 & 0 & 0 & 2 \\
\hline Sometimes lying & 3 & 1 & 3 & 1 & 0 & 0 & 4 \\
\hline Lazy & 0 & 1 & 0 & 0 & 0 & 1 & 1 \\
\hline Arrogant & 1 & 1 & 0 & 1 & 1 & 0 & 2 \\
\hline Heartbreaker & 1 & 1 & 0 & 1 & 1 & 0 & 2 \\
\hline Sometimes angry & 2 & 1 & 2 & 1 & 0 & 0 & 3 \\
\hline $\begin{array}{l}\text { SUM } \\
\text { Column percentages } \\
\text { based on the number of } \\
\text { documents }\end{array}$ & $\begin{array}{l}11 \\
(\% 61)\end{array}$ & $\begin{array}{l}14 \\
(\% 58)\end{array}$ & $\begin{array}{l}12 \\
(\% 92)\end{array}$ & $\begin{array}{l}6 \\
(\% 43)\end{array}$ & $\begin{array}{l}5 \\
(50)\end{array}$ & $\begin{array}{l}2 \\
(\% 40)\end{array}$ & 25 \\
\hline $\mathrm{N}=$ Documents & 18 & 24 & 13 & 14 & 10 & 5 & 42 \\
\hline
\end{tabular}

As seen in Table 3, there was no notable difference between girls and boys in the number of attributing good moral traits to their peers (see "the column percentages based on the number of documents" in table 3). From the age of 7 to 10 , there was a reduction in bad moral traits to Muslim peers. Students in the age group of 7-8 expressed their peers' bad moral traits 12 times, while those in the 9-10 age group said these six times. From 10 to 12 , the number of bad moral 
traits attributed to peers continued at similar proportions. However, these traits were less expressed after age 12 .

\section{Moral Characteristics for Christian Peers by Gender and Age}

Table 4

Good Moral Traits Attributed to Christian Peers by Gender and Age

\begin{tabular}{|c|c|c|c|c|c|c|c|}
\hline & Girl & Boy & $\begin{array}{l}7-8- \\
\text { year- } \\
\text { olds }\end{array}$ & $\begin{array}{l}\text { 9-10- } \\
\text { year-olds }\end{array}$ & $\begin{array}{l}\text { 11-12- } \\
\text { year- } \\
\text { olds }\end{array}$ & $\begin{array}{l}13-14- \\
\text { year- } \\
\text { olds }\end{array}$ & Total \\
\hline \multicolumn{8}{|l|}{ Christian Peers } \\
\hline \multicolumn{8}{|l|}{ Moral characteristics } \\
\hline \multicolumn{8}{|l|}{ Good moral traits } \\
\hline Trustworthy & 1 & 1 & 0 & 0 & 1 & 1 & 2 \\
\hline Non-brawler & 0 & 2 & 1 & 1 & 0 & 0 & 2 \\
\hline Non-swearer & 0 & 1 & 1 & 0 & 0 & 0 & 1 \\
\hline Accuracy and honesty & 0 & 4 & 2 & 0 & 0 & 2 & 4 \\
\hline Hardworking & 1 & 4 & 3 & 2 & 0 & 0 & 5 \\
\hline Helpful & 6 & 10 & 6 & 6 & 3 & 1 & 16 \\
\hline Friendly & 1 & 1 & 2 & 0 & 0 & 0 & 2 \\
\hline Patient & 1 & 1 & 1 & 1 & 0 & 0 & 2 \\
\hline Sharing & 1 & 1 & 1 & 0 & 1 & 0 & 2 \\
\hline Joking & 2 & 0 & 1 & 0 & 1 & 0 & 2 \\
\hline Smiling & 2 & 1 & 1 & 1 & 0 & 1 & 3 \\
\hline SUM & 15 & 26 & 19 & 11 & 6 & 5 & 41 \\
\hline $\begin{array}{l}\text { Column percentages } \\
\text { based on the number } \\
\text { of documents }\end{array}$ & $(\% 83)$ & $(\% 108)$ & $(\% 146)$ & $(\% 79)$ & $(\% 60)$ & $(\% 100)$ & \\
\hline $\mathrm{N}=$ Documents & 18 & 24 & 13 & 14 & 10 & 5 & 42 \\
\hline
\end{tabular}

As seen in Table 4, the boys more expressed their Christian peers' good traits than girls (See "the column percentages based on the number of documents" in Table 2). The 7-8 age group mostly attributed good moral traits to their Christian peers. The number of good traits attributed to Christian peers from 7 to 12 years is decreasing. After the age of 12 , the data shows a rise in the number of good moral traits attributed. 
Table 5

Bad Moral Characteristics Attributed to Christian Peers by Gender and Age

\begin{tabular}{|c|c|c|c|c|c|c|c|}
\hline & Girl B & Boy & $\begin{array}{l}7-8- \\
\text { year- } \\
\text { olds }\end{array}$ & $\begin{array}{l}9-10- \\
\text { year-olds }\end{array}$ & $\begin{array}{l}11-12- \\
\text { year- olds }\end{array}$ & $\begin{array}{l}13-14- \\
\text { year- } \\
\text { olds }\end{array}$ & Total \\
\hline \multicolumn{8}{|l|}{ Christian Peers } \\
\hline \multicolumn{8}{|l|}{ Moral characteristics } \\
\hline \multicolumn{8}{|l|}{ Bad moral traits } \\
\hline Untrusworty & 1 & 3 & 1 & 1 & 2 & 0 & 4 \\
\hline Brawler & 5 & 4 & 4 & 2 & 2 & 1 & 9 \\
\hline Swearer & 0 & 2 & 1 & 0 & 1 & 0 & 2 \\
\hline Lying & 5 & 3 & 3 & 3 & 1 & 1 & 8 \\
\hline Sometimes lying & 3 & 4 & 3 & 4 & 0 & 0 & 7 \\
\hline Lazy & 1 & 1 & 0 & 1 & 1 & 0 & 2 \\
\hline Arrogant & 3 & 0 & 0 & 2 & 1 & 0 & 3 \\
\hline Heartbreaker & 2 & 1 & 0 & 1 & 2 & 0 & 3 \\
\hline Non-sharing & 2 & 0 & 1 & 1 & 0 & 0 & 2 \\
\hline Unsmiling & 0 & 1 & 0 & 0 & 1 & 0 & 1 \\
\hline SUM & 22 & 19 & 13 & 15 & 11 & 2 & 41 \\
\hline $\begin{array}{l}\text { Column percentages } \\
\text { based on the number } \\
\text { of documents }\end{array}$ & $(\% 122)$ & $(\% 79)$ & $(\% 100)$ & $(\% 107$ & $(\% 110)$ & $(\% 47)$ & \\
\hline $\mathrm{N}=$ Documents & 18 & 24 & 13 & 14 & 10 & 5 & 42 \\
\hline
\end{tabular}

As seen in Table 5, the girls more expressed their Christian peers' bad moral traits than boys (See. "the column percentages based on the number of documents" in Table 5). The number of bad moral attributes attributed to Christian peers from 7 to 12 age showed an increase. However, this decreased substantially in the 13-14 age group.

\section{Friendship Choices}

Table 6

Friendship Choices by Age and Gender

\begin{tabular}{lllll}
\hline & $\begin{array}{l}\text { I choose } \\
\text { everyone } \\
(\mathrm{N}=12)\end{array}$ & $\begin{array}{l}\text { Moral reasoning } \\
\text { in choosing } \\
\text { friendship }(\mathrm{N}=16)\end{array}$ & $\begin{array}{l}\text { I choose } \\
\text { Christians } \\
(\mathrm{N}=2)\end{array}$ & $\begin{array}{l}\text { I choose } \\
\text { Muslims } \\
(\mathrm{N}=12)\end{array}$ \\
\hline Gender: Girl, Number $(\%)$ & $4(33.3)$ & $10(62.5)$ & 0 & $5(41.7)$ \\
\hline Gender: Boy, Number $(\%)$ & $8(66.7)$ & $6(37.5)$ & $2(100.0)$ & $7(58.3)$ \\
\hline Age: $7-8$-year-olds, Number $(\%)$ & $9(75.0)$ & $1(6.3)$ & 0 & $3(25.0)$ \\
\hline Age: $9-10$-year-olds, Number $(\%)$ & $3(25.0)$ & $6(37.5)$ & $2(100.0)$ & $4(33.3)$ \\
\hline Age: $11-12$-year- olds, Number $(\%)$ & 0 & $6(37.5)$ & 0 & $3(25.0)$ \\
\hline Age: $13-14$-year- olds, Number $(\%)$ & 0 & $3(18.8)$ & 0 & $2(16.7)$ \\
\hline N = Documents & $12(28.6 \%)$ & 16 & 2 & 12 \\
& & $(38.1 \%)$ & $(4.8 \%)$ & $(28.6 \%)$ \\
\hline
\end{tabular}


As shown in Table 6, 12 students stated that they were friends with everyone, and among these, 4 were girls, 8 were boys. Nine are 7-8-years-olds, and 3 were 9-10-year-olds. There was no student in the 11-14 age group in this category. Sixteen students were evaluating moral characteristics while choosing a friend. Ten of them were girls, and 6 were boys. One student was 7-8-year-olds, 6 were 9-10-year-olds, and 6 were 11-12-year-olds, and 3 were 13-14-yearolds. Two male students, who were 9-10-year-olds, choose their Christian peers. Whereas 12 students, seven boys and five girls, chose their Muslim peers. Three of them were 7-8-yearolds, 4 were 9-10-year-olds, three were 11-12- year-olds, and 2 were 13-14-year-olds.

\section{Discussion}

\section{Peer Appearances Reflecting the Religious Differences in the Drawings by Gender and} Age

Twenty students, seven boys and 13 girls, who participated in the study had indications that reflected religious differences (See Appendix I/Figure 1 and 2). The most common headscarf, the cross, church, and mosque in the pictures are the most noticeable differences in social life. "Smoking," "drinking alcohol," "eating pork," and "using the drug" have been explained by some students as Christian religious signs. However, "not smoking and not drinking alcohol" is also described as a religious indicator of Muslims. These habits can't be religious differences between Christians and Muslims. However, due to children's perception this way in the interviews, it is coded as a religious difference. These stereotypes stemmed from groups' norms and beliefs ascribed to Christian peers rather than religious symbols but are removed from their peers. Alcohol and pork are prohibited in Islam. However, there is no ban on smoking. There are many Muslims and Christians who drink alcohol and use drugs. In our previous research, similarly, similar religious-cultural stereotypes were attributed to Christian peers (Güleç, 2019). For the most typical drawings (See Appendix I/ Figures 1 and 2): Student 37 and Student 34). Student 37: The Muslim person in the drawing is Muhammad. He is a smiling person who works as an imam at the mosque. He is a person who has no morally bad trait, helping everyone and especially the poor. He fulfills his religious duties entirely and does not smoke or drink alcohol. Gandalf, who is Christian, is a peddler. He is a brawler person who has no morally good trait. He smokes, drinks alcohol. Student 34: The Muslim person in the drawing is 
Muhammad. He is an imam at the mosque, fulfilling his prayers and helping the poor. The Christian person drawn is Thomas. He works as a priest at the church. He treats people from other religions at a distance. He is also prejudiced against Muslims and excludes them.

Generally speaking, the religious social images drawn in this study were portrayed in a peaceful manner where extreme representations of the other were very few. Names attributed to peers drawn were commonly Muslim and Christian names with no negative connotations. There was no noticeable significant social status difference in the professions attributed to peers. There were no signs or symbols such as threats, exclusion or humiliation. In this sense, the positive drawings and depictions of Turkish-German Muslim children about their Christian peers appeared to be promising for immigrant and host children in the context of Germany. Nevertheless, this study wasbased only on the opinions of Muslim children. As a matter of fact, the results of some studies conducted with Jewish and Arab children with HFD (Teichman, 2001; Teichman \& Zafrir, 2003; Yedidia \& Lipschitz-Elchawi, 2012) revealed clear differences between children's figure drawings. While Jewish children described Arab images with more negative social traits, Arab children described Jewish images with more positive social traits. The active conflict environment between Jews and Arabs leads to very different and extreme representations (Teichman, 2001; Teichman \& Zafrir, 2003; Yedidia \& Lipschitz-Elchawi, 2012). As a contextual factor, given that there is no active and hostile conflict between the Muslim and Christian groups in Germany, it will be more promising in future research to see that host Christian children portray their Muslim peers with the same moderate religious images.

As previously mentioned in this study, girls used religious indicators more than boys. At the same time, the number of indicators describing religious differences increased with age. The drawings in the age group of the 7-8 age group included the headscarf, the crosses, and churches. In 9-14-year-olds, there were more religious indicators: places of worship (church, mosque), materials of worship (Bible, prayer bead, prayer rug, skullcap), clergymen (imam, priest) and crucifixion (See. The "Column percentages based on the number of documents" in Table 1). In our previous study, the number of religious indicators in children's drawings increased as age increased (Güleç, 2019). Similarly, in some studies with HDF, the number of indicators reflecting ethnic differences in children's pictures increased as they got older (Teichman, 2001; Teichman \& Zafrir, 2003). 
There was the parallelism between our research on religious labels and religious categories and the answers to open-ended questions. Although this parallelism is not seen in every age group, it is generally seen in the pictures after the age of 9. During the interviews, it was understood that all 7-year-old children were aware of some religious labels. However, some children in 78 age groups confused ethnic and religious labels in their drawings. German and Turkish flagged human figures were mostly in this age group. Similarly, in the study of Takriti and colleagues, there was some confusion about religion, nation, and languages in the third and fourth graders. It was understood that all 9-14-year-old children were able to make religious categorization (As stated above, children who express different beliefs regarding the religious groups) in interviews about drawings and responses concerning open-ended questions.

Similarly, in the study of van der Straten Waillet and Roskam (2012a), 7-year-olds did not make religious categorization. However, all children aged 11 years had acquired this ability. Although all children in heterogeneous schools understand religious categorization, 11-year-olds reached this stage in the homogeneous schools. In this study, due to the lack of information from the students, complete information about class composition could not be obtained. The study was conducted with the students at the schools where the author used to teach for 1 year. As a researcher, the author observes that these schools and classes are generally heterogeneous. In fact, in the interviews, many students who can provide information on this subject expressed the heterogeneous structure of their classrooms.

\section{Moral Characteristics Attributed to Muslim and Christian Peers by Gender and Age}

In comparison to the boys, the girls were more likely to attribute positive moral traits to their Muslim peers. In comparison to the girls, the boys attributed positive moral traits to their Christian peers more. It could be said that there is more in-group favoritism in girls in this study. However, to say that this in-group favoritism causes out-group prejudice goes beyond the limits of this study. Indeed, in-group favoritism in a study results from a more positive assessment ingroup, compared to a less positive or impartial evaluation to the out-group (Verkuyten, 2007b). According to some studies, in-group favoritism in some cases causes out-group prejudice (Brewer, 1999; Cameron et al., 2001). However, there are also studies that reveal that increasing positive attitudes in the in-group does not always lead to out-group prejudice and may even contribute to positive attitudes out-group (Phinney et al., 1997). 
In this study, the level of religious commitment of students to their groups is unknown. However, given that the religious identities of Muslim immigrant children in Europe are salient (de Hoon \& van Tubergen, 2014; Güngör et al., 2012; Jacob \& Kalter, 2013; Verkuyten \& Thijs, 2010), it can be thought that this will increase the commitment of children to their groups. Indeed, many studies have revealed that religious prejudice is more common among people who are strongly connected to religious groups (Altemeyer, 2003; Altemeyer \& Hunsberger, 1992; Jackson \& Hunsberger, 1999; Saroglou et al., 2004).

As age increases, the number of good morale traits attributed to peers within the group also increases, but the number of bad morale traits decreases. 11-12 years old group is a group that attributes at most good moral traits to their peers. Verkuyten and Thijs (2010) found that all early adolescents who had more positive feelings towards their groups had a strong religious group identity. Christian and Muslim early adolescents with a strong religious identity had more negative feelings towards non-believers than those with a weak religious identity (Verkuyten $\&$ Thijs, 2010). In this sense, keeping in mind that this research is carried out on a small sample and qualitative research does not aim to draw conclusions, it could be said that the Muslim children and especially the girls who participated in the research have a strong religious group identity.

As the age of the children increases, the good moral traits attributed to Christian peers decrease. However, there is a rise in the number of good moral traits attributed to 12 . The 7-8 age group attributed the best moral qualities to their peers. Even though the bad moral attributes attributed to Christian peers increase from 7 to 12 years, it drops after 12 years. Therefore, in terms of this research, it could be said that the religious prejudice between the ages of 7-12 tends to increase but tends to decrease after age 12. However, as stated above, considering the limited sample size and qualitative nature of this study, this study's results are similar to previous studies on religious prejudice and discrimination (Güleç, 2019; Takriti et al., 2006; Van der Straten Waillet \& Roskam, 2012a).

In summary, it is beyond this study's remit to precisely determine why in-group favoritism increases with age. However, it is possible to say that this in-group favoritism was different from children living in countries such as the Netherlands and did not result from outgroup threat and perceived discrimination. This in-group favoritism is more likely to stem from a strong 
sense of religious group identity among Muslim immigrants and affiliation with Muslim communities' norms and beliefs. In some cases, although there are anti-Muslim thoughts and attitudes in Germany (Çelik, 2015; Savelkoul et al., 2012), this is not on a level that will cause a great threat and discrimination like in the Netherlands. Definitely speaking, the actual causes of in-group favoritism in Muslim children and which socio-cultural and religious situations cause out-group prejudice should be investigated. Future research should include the nature of inter-religious relations in Germany's context and contextual factors (Van der Straten Waillet \& Roskam, 2013) like participants' religious-cultural structure and family religious socialization, school composition, classroom composition, and neighborhood composition. In this study, these contextual factors were not included in the study due to the failure to interview parents.

\section{Friendship Choices by Gender and Age}

Both girls and boys prefer friends within their group (Muslim peers) rather than outside their group (Christian peers). This result was in line with the studies that reveal Christian and nonreligious 10-year-olds (Windzio \& Wingens, 2014) and 13-year-olds adolescents (Leszczensky $\&$ Pink, 2016) prefer their religious groups or groups that are historically and religiously close to them.

The boys preferred their group more than the girls. Given the strong relationship between ethnic and religious ties (Güngör et al., 2012; Maliepaard et al., 2010), this gender difference in religious in-group and out-group friendship preferences support studies that reported that boys prefer more social distance (Verkuyten \& Kinket, 2000), They like to be friends with ethnically similar peers (Shih, 1998). The girls also choose their groups to a certain extent, but they go beyond group norms and are more likely to make friends based on moral assessment.

Like the previous study (Hitti et al., 2017; Killen \& Stangor, 2001), in this sample, minority group Muslim children made their friendship preferences mostly according to moral reasoning (social justice, empathy, and fairness). 7-8 age group is the group that least makes moral reasoning in friendship choices. In the pictures they draw, the moral traits (positive or negative) they attribute to Christian and Muslim peers are similar. This age group often stated that they "are friends with everyone" without considering the group norms or moral traits. Between the ages of 9-12 are the group that considers moral reasoning when making friendship choices. 
These children misjudged the direct religion-based (religious group norms and values) evaluation and chose friends with moral reasoning. They answered the question of "Which religion do you become friends with most at school?" as follows: 12-year-old female student said: "For me, it is enough that they are a good person. Religion, language, and race are of no importance." This student stated that he was not friends with the Muslim person he drew because of being arrogant. Another 10-year-old female student said: "Religion does not matter for me in friendship. A person who does not lie is enough." The Muslim person drawn by this student is benevolent and sharing; the Christian person is helpful and friendly. For this reason, he stated that he made friendships with both Christian and Muslims. These results are in line with studies that reveal that adolescents refuse exclusion based on gender, group membership, and ethnicity (Killen \& Stangor, 2001; Phinney \& Cobb, 1996).

It is understood that some students choose their friends according to their religious group norms. The 11-year-old male student said: "I'm more easily friends with Muslims. Christians' living styles and their foods and drinks are not like Muslims." Another 11-year-old student said that she is not friends with Muslims who act in a negative way. For this student, they mentioned that even if a Christian person is a good person, it is difficult to be friends with them particularly if he have a job that goes against Islamic values. This could include owning a gambling house owner (casino) which is considered a sin in Islam.

As seen in some studies (Abrams et al., 2008; Verkuyten \& Slooter, 2008), in some cases, children do not judge morality and group membership independently when moral violations are associated with group membership.This research shows examples of this. The 14-year-old female student said about a priest he drew: "I would never make friends with him because he was biased against Muslims and excluded them." The student did not mention any other traits or good qualities of this person. In other words, she rejected someone who he perceived as not respecting their group norms and values.

\section{Limitations and Future Research Directions}

Limitations of this study warrant attention. First, conducting this study with a qualitative methodological procedure does not allow generalization of the findings, the findings are limited to the participants in this study. Second, this study sample was small and cross-sectional, it could not provide precise information about the causal aspects of the relationships between 
variables. To identify the causal aspects of relationships, there is a need for qualitative and longitudinal international studies in large samples. The third limitation of this study was that it was conducted in a unilateral manner and homogeneous (only German Muslim Turkish Children). According to a dynamic inter-group perspective (Rupert Brown \& Zagefka, 2011), in order to better understand the intergroup relations, it is important that the research is carried out intergroup and that the participants have a heterogeneous structure. The majority of the comparative studies in the literature are quantitative. Future research could be carried out in heterogeneous structure samples, using an intergroup and mixed research design. Fourth, since the request to meet parents is not accepted by parents, some contextual factors such as family religiosity levels, socio-economic status, quality of religious education they receive, and whether children participate in religious activities could not be included. As a matter of fact, while doing research with immigrant children, some obstacles and difficulties may occur. These children may and have experienced some difficulties in the new country, at home and at school. These conditions require not only sensitivity for researchers, but also awareness of cultural lenses in which they examine and interpret these experiences (Kirova \& Emme, 2007).

\section{Conclusion Recommendations and Applications}

In this study, it was seen that religious indicators, signs, and symbols emerged effectively through the drawing method. Drawings depicting religious differences and numbers of religious differences in the drawings increased with age group of the children. In this sense, the art of drawing may be used as a diagnostics method in more studies in determining the development of religious concepts in children. In order to use this method more effectively, individual discussions about the pictures should be made. Indeed, in some cases, there may be some differences between what is drawn and what is described especially in older children. In addition, it is necessary to reveal the characteristics drawn, by asking separate questions about the people drawn, other than the children's description. Among the people drawn at first glance negative depictions of religious social images were insignificant. However, interviews about the individual drawings and answers to the open-ended questions revealed the difference in the moral traits attributed to their group and the other group.

In the present study, children aged 7-8 could not religious categorization even if they knew some religious labels. It was understood that all 9-14-year-old children were able to make religious categorization in interviews about drawings and responses in relation to open-ended 
questions. In this sample, in-group favoritism increases steadily between the ages of 9-12 and decreases slightly after the age of 12 . It is known that in-group favoritism does not always cause prejudice outside the group. However, based on studies that reveal that religious identities of Muslim immigrant children in Europe and their group norms are salient, it is possible to say that this in-group favoritism could lead to out-group prejudice. In addition, friendship preferences were at most made according to moral reasoning. Those who made moral evaluation the most were between 9-12-year-olds. Rejecting direct religion-based evaluation (group identity, group norms, and values), these children based their friendships on moral reasoning. These age-related results may be used to reflect educational implications. In this sense, intervention implications before 9 years old may be employed to prevent religious-based prejudice which tends to increase with age. Thus, these types of prejudices developed in childhood may have permanent effects in adulthood. Here, intercultural and religious education is very important. Interreligious education, in parallel with the development of religious belief and religious identity of students, should encourage both teaching their own religious tradition and teaching the theological foundations of other religions. The intercultural religious education curriculum should focus on similarities rather than differences between religions. Religions' central doctrine, despite differences, was accepting and loving others including people who think and act differently. Besides, some studies support the idea that children were potentially prone to tolerance (Killen, Lee-Kim, McGlothlin, \& Stangor, 2002; Killen \& Stangor, 2001) when contextual factors were excluded. Thus, the inclination to be prejudiced against other religions and their members may be directed to tolerance through moral necessity.

In addition, increasing intergroup contact (Feddes, Noack, \& Rutland, 2009; McGlothlin \& Killen, 2006; Rutland et al., 2005) could lead to a reduction of prejudices, by directing children to moral reasoning, justice and empathic assessment in peer relationships. Here, the democratic and pluralistic climate created by schools is of critical importance. Hence, schools must create communities based on the common good and empathy that can unite people around integrative social values such as tolerance and "civil respect" (Halstead \& McLaughlin, 2005), regardless of which religion persons belong to (Van der Straten Waillet \& Roskam, 2013). With the curriculum and course materials, the teacher in the classroom also is an essential source of information and a model for students. If the teachers do not respect the differences and do not show this with their behavior, even an excellent cross-cultural and inter-religious curriculum will not be useful (Abu-Nimer \& Smith, 2016). 


\section{Acknowledgment}

This research did not benefit from any funds, either private or public. I'm grateful to the students who studied at Dr.-Johannes-Faust-Schule, Schömberg Schule, Nordstadt Schule, Otterstein Schule, Osterfeld Realschule, and Brötzinger Schule in the Pforzheim educational region where I worked as a teacher during the 2017-2018 academic year for their voluntary participation in this study.

\section{Statements of Ethics and Conflict of Interest}

"I, as the Corresponding Author, declare and undertake that in the study titled as "A Contrastive Study on the Generic Structure and Socio-pragmatic Proclivities in Acknowledgements", scientific, ethical and citation rules were followed; Turkish Online Journal of Qualitative Inquiry Journal Editorial Board has no responsibility for all ethical violations to be encountered, that all responsibility belongs to the author/s and that this study has not been sent to any other academic publication platform for evaluation." This research titled " Muslim and Christian Peer Images in Turkish-German Muslim Children's Human Figure Drawings" was approved by Hac1 Bektaş Veli University Ethics Committee with the number 08 meeting dated 12.03.2020. Ethical issues were considered throughout the study. There is no conflict of interest in this study.

\section{References}

Aboud, F. (1988). Children and prejudice. New York: Basil Blackwell.

Aboud, F., \& Amato, M. (2001). Developmental and socialization influences on intergroup bias. In R Brown \& S. Gaertner (Eds.), Blackwell handbook in social psychology: Intergroup processes (pp. 65-85). UK: John Wiley \& Sons, Ltd.

Abrams, D., Rutland, A., Ferrell, J. M., \& Pelletier, J. (2008). Children's judgments of disloyal and immoral peer behavior: Subjective group dynamics in minimal intergroup contexts. Child Development, 79(2), 444-461. https://doi.org/10.1111/j.1467-8624.2007.01135.x

Abu-Nimer, M., \& Smith, R. K. (2016). Interreligious and intercultural education for dialogue, peace and social cohesion. International Review of Education, 62(4), 393-405. https://doi.org/10.1007/s11159-016-9583-4 
Altemeyer, B. (2003). Why do religious fundamentalists tend to be prejudiced? International Journal for the Psychology of Religion, 13(1), 17-28. https://doi.org/10.1207/S15327582IJPR1301_03

Altemeyer, B., \& Hunsberger, B. (1992). Authoritarianism, religious fundamentalism, quest, and prejudice. International Journal for the Psychology of Religion, 2(2), 113-133. https://doi.org/10.1207/s15327582ijpr0202_5

Bar-Tal, D. (1996). Development of social categories and stereotypes in early childhood: The case of "The Arab" concept formation, stereotype and attitudes by Jewish children in Israel. International Journal of Intercultural Relations, 20(3-4), 341-370. https://doi.org/10.1016/0147-1767(96)00023-5

Bennett, M., Barrett, M., Karakozov, R., Kipiani, G., Lyons, E., Pavlenko, V., \& Riazanova, T. (2004). Young children's evaluations of the ingroup and of outgroups: A multi-national study. Social Development, 13(1), 124-141. https://doi.org/10.1046/j.14679507.2004.00260.x

Bigler, R. S., \& Liben, L. S. (2006). A developmental intergroup theory of social stereotypes and prejudice. Advances in Child Development and Behavior, 34, 39-89. https://doi.org/10.1016/s0065-2407(06)80004-2

Bombi, A. S., Cannoni, E., \& Pinto, G. (2007). Pictorial assessment of interpersonal relationships: An analytic system for understanding childrens drawings $=P A I R$. Firenze: Firenze University Press.

Bombi, A. S., \& Pinto, G. (1994). Making a dyad: Cohesion and distancing in children's pictorial representation of friendship. British Journal of Developmental Psychology, 12(4), 563-575. https://doi.org/10.1111/j.2044-835X.1994.tb00656.x

Branscombe, N. R., Schmitt, M. T., \& Harvey, R. D. (1999). Perceiving pervasive discrimination among African Americans: Implications for group identification and well-being. Journal of Personality and Social Psychology, 77(1), 135-149. https://doi.org/10.1037/0022-3514.77.1.135

Brewer, M. B. (1999). The psychology of prejudice: Ingroup love and outgroup hate? Journal of Social Issues, 55(3), 429-444. https://doi.org/10.1111/0022-4537.00126

Brooks, M. (2003b). Drawing thinking, meaning. Retrieved January 14, 2020, from TRACEY [an electronic journal about contemporary drawing issues]. Loughborough: University of Loughborough website: http://www.lboro.ac.uk/ departments/ac/tracey/thin/brooks.html 
Brooks, M. (2003a). Drawing to learn, young children: Beyond the journal, September. Retrieved January 14, 2020, from Washington: National Association for the Education of Young Children website: http://www.journal.naeyc.org/btj/200309

Brown, Rupert, \& Zagefka, H. (2011). The dynamics of acculturation: An intergroup perspective. Advances in Experimental Social Psychology, 44, 129-184. https://doi.org/10.1016/B978-0-12-385522-0.00003-2

Brüß, J. (2005). Proud but isolated? Effects of in-group favouritism and acculturation preferences on inter-ethnic attitudes and contact between German, Turkish and resettler adolescents. Journal of Ethnic and Migration Studies, 31(1), 3-27. https://doi.org/10.1080/1369183042000305663

Cadge, W., \& Ecklund, E. H. (2007). Immigration and religion. Annual Review of Sociology, 33, 359-379. https://doi.org/10.1146/annurev.soc.33.040406.131707

Cameron, J. A., Alvarez, J. M., Ruble, D. N., \& Fuligni, A. J. (2001). Children's lay theories about ingroups and outgroups: Reconceptualizing research on prejudice. Personality and Social Psychology Review, 5(2), 118-128. https://doi.org/10.1207/S15327957PSPR0502_3

Çelik, Ç. (2015). 'Having a German passport will not make me German': Reactive ethnicity and oppositional identity among disadvantaged male Turkish second-generation youth in Germany. Ethnic and Racial Studies, 38(9), 1646-1662. https://doi.org/10.1080/01419870.2015.1018298

Cheadle, J. E., \& Schwadel, P. (2012). The 'friendship dynamics of religion,' or the 'religious dynamics of friendship'? A social network analysis of adolescents who attend small schools. Social Science Research, 41(5), 1198-1212. https://doi.org/10.1016/j.ssresearch.2012.03.014

Connor, P. (2010). Contexts of immigrant receptivity and immigrant religious outcomes: The case of Muslims in Western Europe. Ethnic and Racial Studies, 33(3), 376-403. https://doi.org/10.1080/01419870902935963

Creswell, J. W., \& Clark, V. L. P. (2011). Designing and conducting mixed methods research. USA: SAGE publications.

de Hoon, S., \& van Tubergen, F. (2014). The religiosity of children of immigrants and natives in England, Germany, and the Netherlands: The role of parents and peers in class. European Sociological Review, 30(2), 194-206. https://doi.org/10.1093/esr/jcu038 
Dovidio, J. F., Gaertner, S. L., \& Saguy, T. (2007). Another view of "we": Majority and minority group perspectives on a common ingroup identity. European Review of Social Psychology, 18(1), 296-330. https://doi.org/10.1080/10463280701726132

Driessnack, M. (2005). Children's drawings as facilitators of communication: A meta-analysis. Journal of Pediatric Nursing, 20(6), 415-423. https://doi.org/10.1016/j.pedn.2005.03.011

Enesco, I., Navarro, A., Paradela, I., \& Guerrero, S. (2005). Stereotypes and beliefs about different ethnic groups in Spain. A study with Spanish and Latin American children living in Madrid. Journal of Applied Developmental Psychology, 26(6), 638-659. https://doi.org/10.1016/j.appdev.2005.08.009

Feddes, A. R., Noack, P., \& Rutland, A. (2009). Direct and extended friendship effects on minority and majority children's interethnic attitudes: A longitudinal study: Direct and extended friendship effects. Child Development, 80(2), 377-390. https://doi.org/10.1111/j.1467-8624.2009.01266.x

Fleischmann, F., \& Phalet, K. (2011). Integration and religiosity among the Turkish second generation in Europe: A comparative analysis across four capital cities. Ethnic and Racial Studies, 1-22. https://doi.org/10.1080/01419870.2011.579138

Furth, G. M. (1989). Secret world of drawings: Healing through art. Canada: Sigo Pr.

Golomb. (1992). The child's creation of pictorial world. Berkeley: University of California Press.

Greenwald, A. G., McGhee, D. E., \& Schwartz, J. L. (1998). Measuring individual differences in implicit cognition: The implicit association test. Journal of Personality and Social Psychology, 74(6), 1464-1480. https://doi.org/10.1037//0022-3514.74.6.1464

Griffiths, J. A., \& Nesdale, D. (2006). In-group and out-group attitudes of ethnic majority and minority children. International Journal of Intercultural Relations, 30(6), 735-749. https://doi.org/10.1016/j.ijintrel.2006.05.001

Grossetti, M. (2005). Where do social relations come from? Social Networks, 27(4), 289-300. https://doi.org/10.1016/j.socnet.2004.11.004

Güleç, Y. (2019). Perception of Christianity and Christian peers in the drawings of Muslim children: The example of Pforzheim/Germany. Turkish Online Journal of Qualitative Inquiry, 10(2), 215-242. https://doi.org/10.17569/tojqi.403145

Güngör, D., Bornstein, M. H., \& Phalet, K. (2012). Religiosity, values, and acculturation: A study of Turkish, Turkish-Belgian, and Belgian adolescents. International Journal of Behavioral Development, 36(5), 367-373. https://doi.org/10.1177/0165025412448357 
Hallinan, M. T., \& Teixeira, R. A. (1987). Opportunities and constraints: Black-white differences in the formation of interracial friendships. Child Development, 58(5), 13581371. https://doi.org/10.2307/1130627

Halstead, J. M., \& McLaughlin, T. (2005). Are faith schools divisive? In J. Cairns, R. Gardner, \& D. Lawton (Eds.), Faith schools: Consensus or conflict? (pp. 61-73). New York: Routledge.

Hart, R. A. (1992). Children's participation: From tokenism to citizenship. Florence: UNICEF.

Heath, A. F., Rothon, C., \& Kilpi, E. (2008). The second generation in Western Europe: Education, unemployment, and occupational attainment. Annual Review of Sociology, 34(1), 211-235. https://doi.org/10.1146/annurev.soc.34.040507.134728

Herriot, P. (2007). Religious fundamentalism and social identity. New York: Routledge.

Hirschman, C. (2006). The role of religion in the origins and adaptation of 1mmigrant groups in the United States. International Migration Review, 38(3), 1206-1233. https://doi.org/10.1111/j.1747-7379.2004.tb00233.x

Hitti, A., Mulvey, K. L., \& Killen, M. (2017). Minority and majority children's evaluations of social exclusion in intergroup contexts. In N. J. Cabrera \& B. Leyendecker (Eds.), Handbook on positive development of minority children and youth (pp. 281-293). Cham: Springer International Publishing.

Jackson, L. M., \& Hunsberger, B. (1999). An intergroup perspective on religion and prejudice. Journal for the Scientific Study of Religion, 38(4), 509-523 https://doi.org/10.2307/1387609

Jacob, K., \& Kalter, F. (2013). Intergenerational change in religious salience among immigrant families in four European countries. International Migration, 51(3), 38-56. https://doi.org/10.1111/imig.12108

Killen, M., Lee-Kim, J., McGlothlin, H., \& Stangor, C. (2002). How children and adolescents evaluate gender and racial exclusion. Monographs of the Society for Research in Child Development, 67(4), vii-vii. https://doi.org/10.1111/1540-5834.00218

Killen, M., \& Stangor, C. (2001). Children's social reasoning about inclusion and exclusion in gender and race peer group contexts. Child Development, 72(1), 174-186. https://doi.org/10.1111/1467-8624.00272

Kinder, D. R., \& Sears, D. O. (1981). Prejudice and politics: Symbolic racism versus racial threats to the good life. Journal of Personality and Social Psychology, 40(3), 414-31. 
Kirova, A., \& Emme, M. (2007). Critical issues in conducting research with immigrant children. Diaspora, Indigenous, and Minority Education, 1(2), 83-107. https://doi.org/10.1080/15595690701293710

Kowalski, K. (2003). The emergence of ethnic and racial attitudes in preschool-aged children. The Journal of Social Psychology, 143(6), 677-690. https://doi.org/10.1080/00224540309600424

Krampen, M. (1991). Children's drawings: Iconic coding of the environment. New York: Springer.

Laghi, F., Baiocco, R., Cannoni, E., Di Norcia, A., Baumgartner, E., \& Bombi, A. S. (2013). Friendship in children with internalizing and externalizing problems: A preliminary investigation with the pictorial assessment of interpersonal relationships. Children and Youth Services Review, 35(7), 1095-1100. https://doi.org/10.1016/j.childyouth.2013.05.007

Laghi, F., Baiocco, R., Di Norcia, A., Cannoni, E., Baumgartner, E., \& Bombi, A. S. (2014). Emotion understanding, pictorial representations of friendship and reciprocity in school-aged children. Cognition and Emotion, 28(7), 1338-1346. https://doi.org/10.1080/02699931.2014.881779

Leman, P. J., Ben-Hmeda, M., Cox, J., Loucas, C., Seltzer-Eade, S., \& Hine, B. (2013). Normativity and friendship choices among ethnic majority- and minority-group children. International Journal of Behavioral Development, 37(3), 202-210. https://doi.org/10.1177/0165025413477315

Leszczensky, L., Flache, A., \& Sauter, L. (2019). Does the share of religious ingroup members affect how important religion is to adolescents? Applying optimal distinctiveness theory to four European countries. Journal of Ethnic and Migration Studies, 1-19. https://doi.org/10.1080/1369183X.2019.1620419

Leszczensky, L., \& Pink, S. (2016). Intra- and inter-group friendship choices of Christian, Muslim, and Non-religious youth in Germany. European Sociological Review, 72-83. https://doi.org/10.1093/esr/jcw049

Lopez, A. B., Huynh, V. W., \& Fuligni, A. J. (2011). A longitudinal study of religious identity and participation during adolescence. Child Development, 82(4), 1297-1309. https://doi.org/10.1111/j.1467-8624.2011.01609.x

Maliepaard, M., Lubbers, M., \& Gijsberts, M. (2010). Generational differences in ethnic and religious attachment and their interrelation. A study among Muslim minorities in the 
Muslim and Christian Peer Images in Turkish-German Muslim Children's Human Figure Drawings

Netherlands. Ethnic and Racial Studies, 33(3), 451-472. https://doi.org/10.1080/01419870903318169

McGlothlin, H., \& Killen, M. (2005). Children's perceptions of intergroup and intragroup similarity and the role of social experience. Journal of Applied Developmental Psychology, 26(6), 680-698. https://doi.org/10.1016/j.appdev.2005.08.008

McGlothlin, H., \& Killen, M. (2006). Intergroup attitudes of European American children attending ethnically homogeneous schools. Child Development, 77(5), 1375-1386. https://doi.org/10.1111/j.1467-8624.2006.00941.x

Michael, O., \& Rajuan, M. (2009). Perceptions of 'the other' in children's drawings: An intercultural project among Bedouin and Jewish children. Journal of Peace Education, 6(1), 69-86. https://doi.org/10.1080/17400200802658407

Morrow, V., \& Richards, M. (1996). The ethics of social research with children: An overview1. Children \& Society, 10(2), 90-105. https://doi.org/10.1111/j.10990860.1996.tb00461.x

Nesdale, D. (2008). Peer group rejection and children's intergroup prejudice. In S. R. Levy \& M. Killen (Eds.), Intergroup attitudes and relations in childhood through adulthood (pp. 32-46). New York, NY, US: Oxford University Press.

Nesdale, D., Maass, A., Griffiths, J., \& Durkin, K. (2003). Effects of in-group and out-group ethnicity on children's attitudes towards members of the in-group and out-group. British Journal of Developmental Psychology, 21(2), 177-192. https://doi.org/10.1348/026151003765264039

Patton, M. Q. (1987). How to use qualitative methods in evaluation. United States: SAGE Publications.

Phalet, K., Güngör, D., \& Brewster Smith, M. (2009). Cultural continuity and discontinuity in Turkish migrant families: Extending the model of family change. In S. Bekman \& A. Aksu-Koc (Eds.), Perspectives on human development, family, and culture (pp. 241262). Cambridge: Cambridge University Press.

Phinney, J. S., \& Cobb, N. J. (1996). Reasoning about intergroup relations among Hispanic and Euro-American adolescents. Journal of Adolescent Research, 11(3), 306-324. https://doi.org/10.1177/0743554896113003

Phinney, J. S., Ferguson, D. L., \& Tate, J. D. (1997). Intergroup attitudes among ethnic minority adolescents: A causal model. Child Development, 68(5), 955-969. https://doi.org/10.2307/1132044 
Pinto, G., \& Bombi, A. S. (2008). Children's drawing of friendship and family relationships in different cultures. In M. Constance \& M. T. Hanns (Eds.), Children's understanding and production of pictures, drawings, and art theoretical and empirical approaches (pp. 121-154). Ashland, OH, US: Hogrefe \& Huber Publishers.

Quintana, S. M. (1998). Children's developmental understanding of ethnicity and race. Applied and Preventive Psychology, 7(1), 27-45. https://doi.org/10.1016/S09621849(98)80020-6

Rabaglietti, E., Vacirca, M. F., Zucchetti, G., \& Ciairano, S. (2012). Similarity, cohesion, and friendship networks among boys and girls: A one-year follow-up study among Italian children. Current Psychology, 31(3), 246-262. https://doi.org/10.1007/s12144-0129145-2

Rothgerber, H., \& Worchel, S. (1997). The view from below: Intergroup relations from the perspective of the disadvantaged group. Journal of Personality and Social Psychology, 73(6), 1191-1205. https://doi.org/10.1037/0022-3514.73.6.1191

Ruble, D. N., Alvarez, J., Bachman, M., Cameron, J., Fuligni, A., Coll, C. G., \& Rhee, E. (2004). The development of a sense of we: The emergence and implications of children's collective identity. In M. Bennett \& F. Sani (Eds.), The development of the social self. New York: Psychology Press.

Rutland, A. (2004). The development and self-regulation of intergroup attitudes in children. In M. Bennett \& F. Sani (Eds.), The development of the social self. (pp. 247-265). East Sussex, England: Psychology Press.

Rutland, A., Cameron, L., Milne, A. B., \& McGeorge, P. (2005). Social norms and selfpresentation: Children's implicit and explicit intergroup attitudes. Child Development, 76(2), 451-466. https://doi.org/10.1111/j.1467-8624.2005.00856.x

Rutland, A., Killen, M., \& Abrams, D. (2010). A new social-cognitive developmental perspective on prejudice: The interplay between morality and group identity. Perspectives on Psychological Science, 5(3), 279-291. https://doi.org/10.1177/1745691610369468

Sani, F., \& Bennett, M. (2004). Developmental aspects of social identity. In M. Bennett \& F. Sani (Eds.), The development of the social self (pp. 77-99). New York: Psychology Press.

Saroglou, V., Delpierre, V., \& Dernelle, R. (2004). Values and religiosity: A meta-analysis of studies using Schwartz's model. Personality and Individual Differences, 37(4), 721734. https://doi.org/10.1016/j.paid.2003.10.005 
Savelkoul, M., Scheepers, P., Van der Veld, W., \& Hagendoorn, L. (2012). Comparing levels of anti-Muslim attitudes across Western countries. Quality \& Quantity, 46(5), 16171624. https://doi.org/10.1007/s11135-011-9470-9

Schwartz, S. H., \& Huismans, S. (1995). Value priorities and religiosity in four western religions. Social Psychology Quarterly, 58(2), 88. https://doi.org/10.2307/2787148

Seul, J. R. (1999). 'Ours is the way of God': Religion, identity, and intergroup conflict. Journal of Peace Research, 36(5), 553-569. https://doi.org/10.1177/0022343399036005004

Shih, T. A. (1998). Finding the niche: Friendship formation of immigrant adolescents. Youth \& Society, 30(2), 209-240. https://doi.org/10.1177/0044118X98030002004

Smetana, J. G. (2013). Moral development: The social domain theory view. In P. D. Zelazo (Ed.), The Oxford handbook of developmental psychology (Vol 1): Body and mind (pp. 832-863). New York, NY, US: Oxford University Press.

Smith, S., Maas, I., \& van Tubergen, F. (2014). Ethnic ingroup friendships in schools: Testing the by-product hypothesis in England, Germany, the Netherlands and Sweden. Social Networks, 39, 33-45. https://doi.org/10.1016/j.socnet.2014.04.003

Soehl, T. (2017). Social reproduction of religiosity in the 1mmigrant context: The role of family transmission and family formation-evidence from France. International Migration Review, 51(4), 999-1030. https://doi.org/10.1111/imre.12289

Tajfel, H. (1981). Human groups and social categories: Studies in social psychology. New York: Cambridge University Press.

Tajfel, H., \& Dawson, J. L. M. (1965). Disappointed guests: Essays by African, Asian, and west Indian students. London: Oxford University Press.

Tajfel, H., \& Turner, J. C. (2004). The social identity theory of intergroup behavior. In J. T. Jost \& J. Sidanius (Eds.), Political psychology (pp. 276-293). New York: Psychology Press.

Takriti, R. A., Barrett, M., \& Buchanan-Barrow, E. (2006). Children's understanding of religion: Interviews with Arab-Muslim, Asian-Muslim, Christian and Hindu children aged 5-11 years. Mental Health, Religion \& Culture, 9(1), 29-42. https://doi.org/10.1080/13674670512331335677

Teichman, Y. (2001). The development of Israeli children's images of Jews and Arabs and their expression in human figure drawings. Developmental Psychology, 37(6), 749-761. https://doi.org/10.1037//0012-1649.37.6.749 
Teichman, Y., \& Zafrir, H. (2003). Images held by Jewish and Arab children in Israel of people representing their own and the other group. Journal of Cross-Cultural Psychology, 34(6), 658-676. https://doi.org/10.1177/0022022103256847

Turiel, E. (1983). The development of social knowledge: Morality and convention. Cambridge: Cambridge University Press.

Van der Straten Waillet, N., \& Roskam, I. (2012a). Developmental and social determinants of religious social categorization. The Journal of Genetic Psychology, 173(2), 208-220. https://doi.org/10.1080/00221325.2011.600356

Van der Straten Waillet, N., \& Roskam, I. (2012b). Religious discrimination in childhood and adolescence. Archive for the Psychology of Religion, 34(2), 215-242. https://doi.org/10.1163/15736121-12341240

Van der Straten Waillet, N., \& Roskam, I. (2013). Are religious tolerance and pluralism reachable ideals? A psychological perspective. Religious Education, 108(1), 69-87. https://doi.org/10.1080/00344087.2013.747873

Van Tubergen, F. (2007). Religious affiliation and participation among immigrants in a secular society: A study of immigrants in the Netherlands. Journal of Ethnic and Migration Studies, 33(5), 747-765. https://doi.org/10.1080/13691830701359181

Velasco González, K., Verkuyten, M., Weesie, J., \& Poppe, E. (2008). Prejudice towards Muslims in the Netherlands: Testing integrated threat theory. British Journal of Social Psychology, 47(4), 667-685. https://doi.org/10.1348/014466608X284443

Verkuyten, M. (2007a). Religious group identification and inter-religious relations: A study among Turkish-Dutch Muslims. Group Processes \& Intergroup Relations, 10(3), 341357. https://doi.org/10.1177/1368430207078695

Verkuyten, M. (2007b). Religious group identification and inter-religious relations: A study among Turkish-Dutch Muslims. Group Processes \& Intergroup Relations, 10(3), 341357. https://doi.org/10.1177/1368430207078695

Verkuyten, M., \& Kinket, B. (2000). Social distances in a multi ethnic society: The ethnic hierarchy among Dutch preadolescents. Social Psychology Quarterly, 63(1), 75. https://doi.org/10.2307/2695882

Verkuyten, M., \& Slooter, L. (2008). Muslim and Non-Muslim Adolescents' reasoning about freedom of speech and minority rights. Child Development, 79(3), 514-528. Retrieved from http://www.jstor.org/stable/27563500 
Verkuyten, M., \& Thijs, J. (2010). Religious group relations among Christian, Muslim and Nonreligious early adolescents in the Netherlands. The Journal of Early Adolescence, 30(1), 27-49. https://doi.org/10.1177/0272431609342984

Verkuyten, M., Thijs, J., \& Stevens, G. (2012). Multiple identities and religious transmission: A study among Moroccan-Dutch Muslim adolescents and their parents. Child Development, 83(5), 1577-1590. https://doi.org/10.1111/j.1467-8624.2012.01794.x

Verkuyten, M., \& Yildiz, A. A. (2007). National (dis)identification and ethnic and religious identity: A study among Turkish-Dutch Muslims. Personality and Social Psychology Bulletin, 33(10), 1448-1462. https://doi.org/10.1177/0146167207304276

Vermeij, L., van Duijn, M. A. J., \& Baerveldt, C. (2009). Ethnic segregation in context: Social discrimination among native Dutch pupils and their ethnic minority classmates. Social Networks, 31(4), 230-239. https://doi.org/10.1016/j.socnet.2009.06.002

Voas, D., \& Fleischmann, F. (2012). Islam moves west: Religious change in the first and second generations. Annual Review of Sociology, 38(1), 525-545. https://doi.org/10.1146/annurev-soc-071811-145455

Vygotsky, L. S. (1962). Thought and language. Cambridge: MA: MIT Press.

Windzio, M., \& Wingens, M. (2014). Religion, friendship networks and home visits of immigrant and native children. Acta Sociologica, 57(1), 59-75. https://doi.org/10.1177/0001699313481226

Yedidia, T., \& Lipschitz-Elchawi, R. (2012). Examining social perceptions between Arab and Jewish children through human figure drawings. Art Therapy, 29(3), 104-112. https://doi.org/10.1080/07421656.2012.703052

Yıldırım, A., \& Şimşek, H. (2016). Sosyal bilimlere nitel araştırma yöntemleri (10. basım). Ankara: Seçkin yayıncılık.

Ysseldyk, R., Matheson, K., \& Anisman, H. (2010). Religiosity as identity: Toward an understanding of religion from a social identity perspective. Personality and Social Psychology Review, 14(1), 60-71. https://doi.org/10.1177/1088868309349693

Ysseldyk, R., Matheson, K., \& Anisman, H. (2011). Coping with identity threat: The role of religious orientation and implications for emotions and action intentions. Psychology of Religion and Spirituality, 3(2), 132-148. https://doi.org/10.1037/a0021599 


\section{Appendix I}

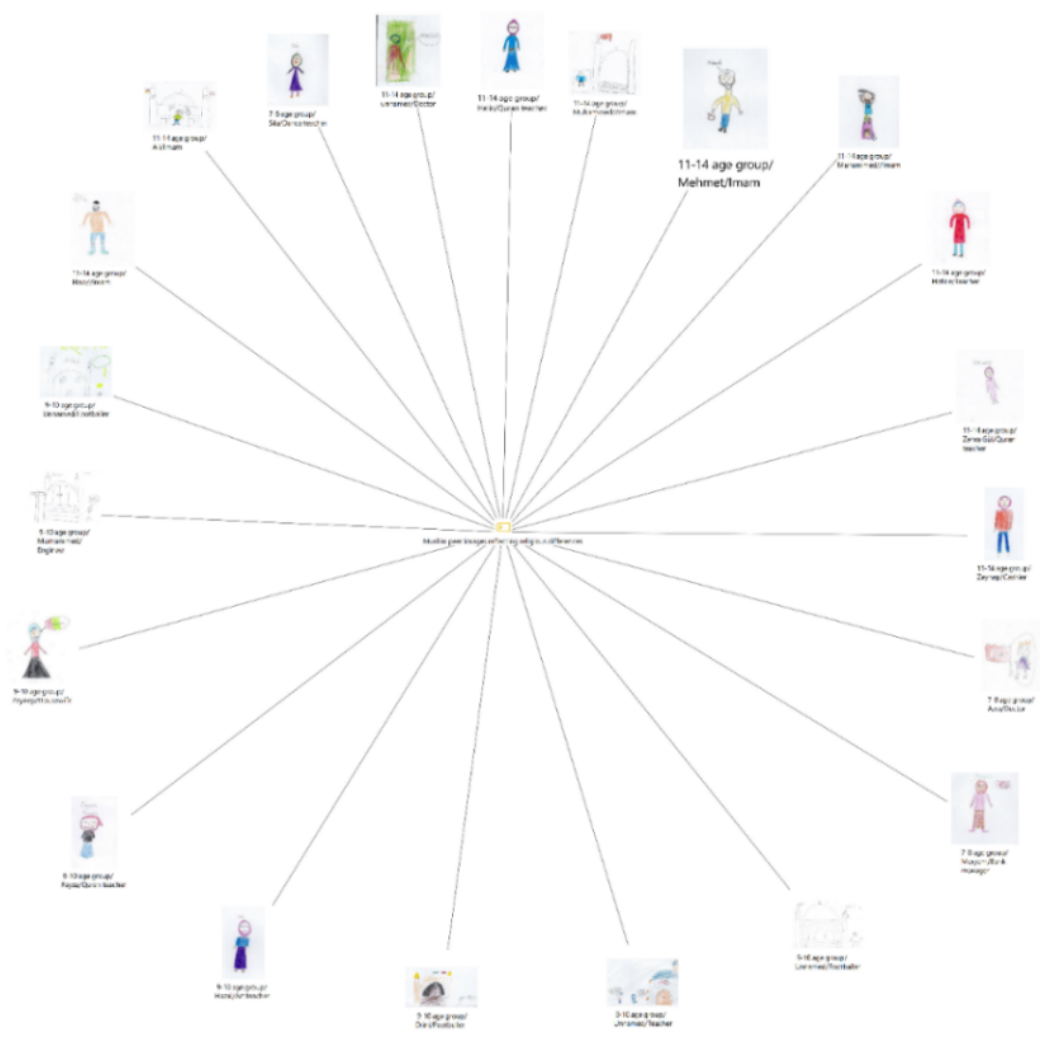

Figure 1. Single-Code Model/ Muslim images reflecting religious differences

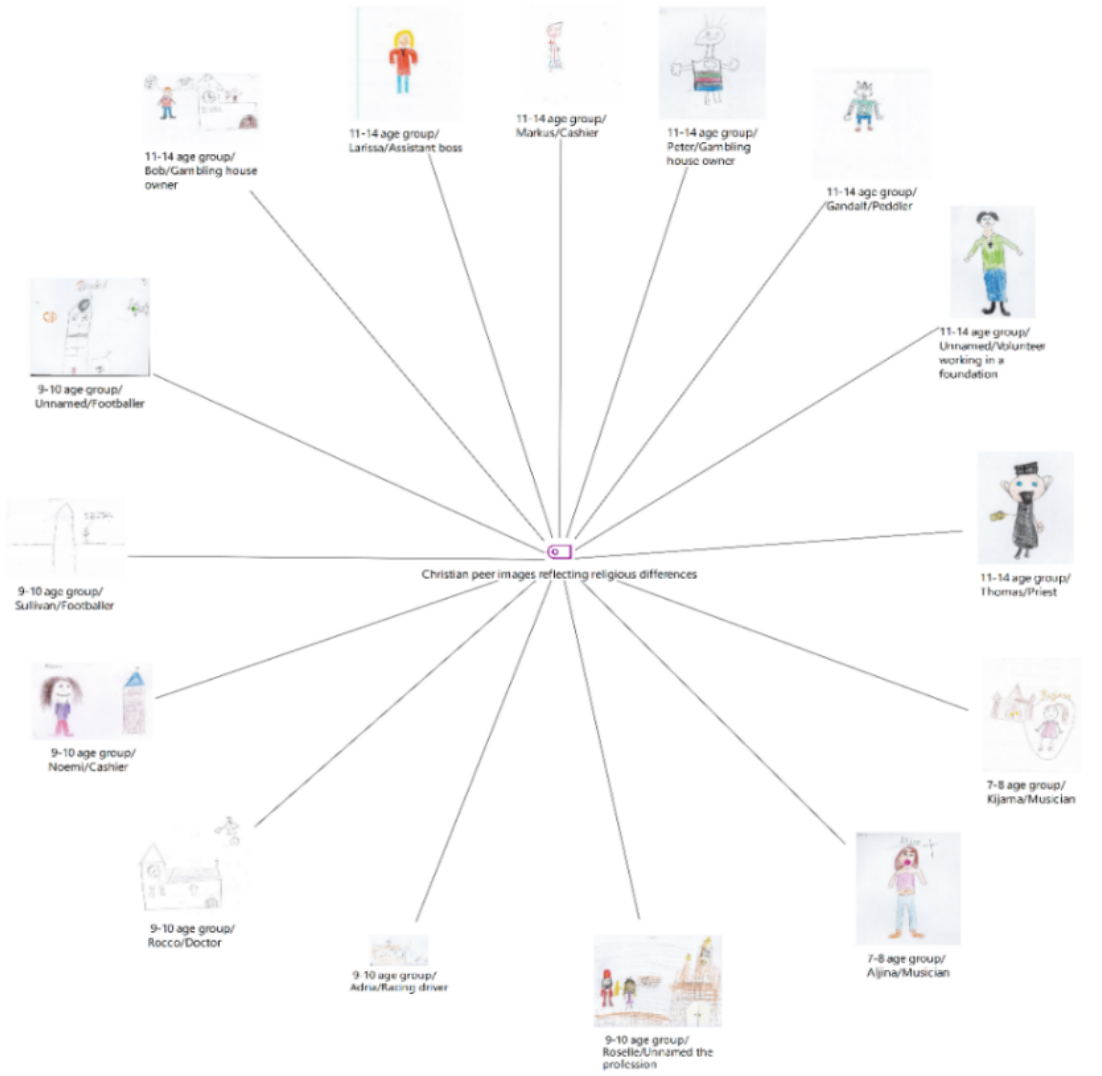

Figure 2. Single-Code Model/ Christian images reflecting religious differences 
Muslim and Christian Peer Images in Turkish-German Muslim Children's Human Figure Drawings 